\title{
Three new Licmophora species (Bacillariophyta: Fragilariophyceae) from Guam, two with an axial wave in the valve
}

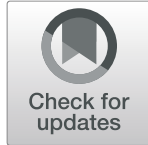

\author{
Ella M. S. Macatugal ${ }^{1}$, Bernadette G. Tharngan ${ }^{1}$ and Christopher S. Lobban ${ }^{2^{*}}$ (D)
}

\begin{abstract}
Background: Diatoms in genus Licmophora are found as epiphytes on marine shores and are members of fouling communities. They can be abundant on natural coral reef substrates such as filamentous algae and as fringes on Halimeda. Biodiversity of benthic tropical diatoms is generally poorly known. Several new species of Licmophora have been reported from Guam but many are still undescribed.
\end{abstract}

Methods: Samples of seaweeds with evident diatom coatings were collected during scuba dives, examined live, preserved in formalin, and processed with nitric acid cleaning following standard practice. Cleaned samples were examined in LM and SEM.

Results: We describe two species unusual in having an axial wave in the valve, and a further long, straight species. L. repanda n. sp. and L. undulata n. sp. were of similar lengths (ca. $200 \mu \mathrm{m}$ long) and both had axial waves but $L$. undulata was more slender with an inflated basal pole, had colonies on mucilage pads vs. long, single-stranded mucilage stalks. In addition, L. undulata had one apical rimoportula vs. two, elongated areolae along the midrib vs. uniform areolae, and the valvocopular advalvar striae ended halfway along, whereas in L. repanda they continued to the end. L. joymaciae n. sp. grew on long, single-stranded mucilage stalks with valves 300-400 $\mu \mathrm{m}$ long, with two apical rimoportulae, and basal pole not inflated. As in L. undulata its valvocopular advalvar striae ended halfway along the band. Stria densities were different at apex vs. base in L. joymaciae but not in the two wavy species. In all species, the 4th pleura had an apical cap and a narrow band with a single row of pores but it was larger in $L$. joymaciae. The other three girdle bands did not present any major differences among the three species but are documented for future comparisons with other species.

Conclusions: Although the morphometric differences are small among the new species and between them and similar known species, the combinations of character states clearly shows that they are different.

Keywords: Araphid diatoms, Benthic diatoms, Coral reefs, Epiphytes, Fouling, Girdle bands, Tropical diatoms, Valvocopula

\section{Introduction}

Diatoms of the genus Licmophora C.A.Agardh are common and sometimes abundant epiphytes on marine shores from the poles to the tropics. As members of "fouling" communities they have attracted the attention of applied scientists (Daniel et al. 1987; Woods and Fletcher 1991; Zargiel and Swain 2014; Ravizza and Hallegraeff 2015). On natural substrates diatoms including Licmophora can

\footnotetext{
* Correspondence: clobban@guam.net

${ }^{2}$ Division of Natural Sciences, University of Guam, Mangilao, GU 96923, USA Full list of author information is available at the end of the article
}

be abundant under some circumstances, e.g., on the filamentous algae cultivated by pomacentrid farmer fish (Lobban and Jordan 2010). In Guam, and probably other tropical locations, Licmophora spp. commonly form fringes around the edges of living Halimeda segments, along with genera such as Climacosphenia and Ardissonea (Lobban et al. 2011). Some species form extensive blooms, e.g., L. colosalis Belando et al. (2016) and L. labianatis Lobban et al. (2018).

Licmophora cells are heteropolar in being clavate or spathulate in valve view and attached at the base. They 
are also heterovalvar, with a basal rimoportula on one valve so that front/back and left/right can be recognized in addition to the epitheca and hypotheca (Lobban et al. 2018). Valves are generally straight, but there are a few curved species, including our recently described $L$. curvata Lobban et al. (2018).

Diatoms with wavy outlines, where the valve outline has a wave form (as opposed to species where the wavy margins are the result of inflations, such as Grammatophora undulata Ehrenberg) are rare. They include Toxarium undulatum Bailey ex Bailey (Mediophyceae) and Neosynedra tortosa (Grunow) D. Williams \& F.E. Round (Fragilariophyceae); in the latter the valve margins undulate but the sternum is straight. One species of Licmophora, L. flucticulata Lobban et al. (2011), has a wavy outline along part of the valve, but because of the weak silicification it is not clear whether the sternum is straight or follows the curves of the valves. L. subundulata Mereschkowsky (1901-1902), has a completely different outline.

In published records of tropical floras, the diversity of Licmophora appears to vary wildly. For example, Hagelstein (1939) reported but did not illustrate 19 taxa from Puerto Rico and the U.S. Virgin Islands; Giffen (1980) likewise listed 9 taxa from Mahé; Navarro (1982) showed 1 species from Puerto Rico; Hein et al. (2008) 3 species from The Bahamas. One difficulty with these lists, especially those lacking illustrations, is that we cannot tell whether the species truly correspond to the European taxa. For instance, L. ehrenbergii, widely reported from tropical locations, appears to occur in Guam but did not match European specimens at the ultrastructural level (Lobban 2013 vs Honeywill 1998).

The difficulties with determining the identity of tropical species are that most of the known species of Licmophora were described from European shores and there are relatively few characters on valves, even when ultrastructure is included. We recently showed that there are many useful characters in the girdle bands (valvocopula and pleurae) (Lobban et al. 2018), but this information has yet to be collected for most (including all European) taxa. Few species have yet been sequenced, and most of those were not European samples. Meanwhile, we have proceeded to analyze Guam Licmophora species that have distinctive features in the valve. Here we report on two species that have an axial wave in the valve and on a further long, straight species.

\section{Methods}

Study samples were collected, processed, and observed by light microscopy (LM) fresh and following preservation, and in SEM whole mounts and acid-cleaned material following standard protocols used in the Lobban lab (Lobban 2015a, b). In brief, samples preserved in formalin were rinsed, boiled with nitric acid and rinsed to neutrality. Drops of the resultant suspension were dried onto cover slips for LM and cellulose nitrate filters for SEM. LM observations were made with a Nikon $80 i$ microscope with differential interference contrast (Nikon Instruments, Redmond, WA, USA). SEM observations were made with a desktop Phenom G2 Pro (PhenomWorld US, Hillsboro, OR, USA).

Terminology follows Lobban et al. (2018) and standard works cited therein.

\section{Results}

\section{SYSTEMATICS}

\author{
Class FRAGILARIOPHYCEAE Round \\ Order LICMOPHORALES Round emend Cox \\ Family Licmophoraceae Kützing \\ Genus Licmophora C.A.Agardh \\ Licmophora repanda, n. sp. Macatugal, Tharngan \& \\ Lobban
}

(Figs. 1 and 2)

\section{Diagnosis}

Colonies on long, single-stranded mucilage stalks. Valve length $190-215 \mu \mathrm{m}$, width $12-18 \mu \mathrm{m}$, without inflated basal pole; 1-2 axial waves mid-valve. Striae $25-30$ in $10 \mu \mathrm{m}$. Apical rimoportulae on both valves, on edge of mantle beyond sternum. Multiscissura with 23-26 slits. Valvocopula with advalvar striae throughout. The 4th pleura an apical cap plus narrow band.

\section{Type material}

Holotype: valve located at $13.6 \mathrm{~mm} \mathrm{E}$ and $9.4 \mathrm{~mm} \mathrm{~S}$ of the reference mark on slide 2459, GU44BV-1 deposited at ANSP Diatom Herbarium, accession \# 20082. Sample collected by C. Lobban and M. Schefter, 28 Oct. 2017, GabGab reef, Apra Harbor, Guam, 13 26' 33.63“ N, $144^{\circ} 38^{\prime} 34.25^{\prime \prime} \mathrm{E}$, Halimeda with fringe of diatoms from $10 \mathrm{~m}$ depth (not in farmer-fish territory). Fig. 1c-e.

\section{Etymology}

Latin, repanda = having a slightly uneven and waved margin.

\section{Additional materials examined}

Observed frequently, especially as a fringe on green calcified seaweeds in the genus Halimeda at $10-15 \mathrm{~m}$ along the GabGab fore-reef. Samples: GU44AL-2A (black sponge with diatom fringe, 20 Nov 2011), GU44AR-3 (Halimeda fringe, 12 Aug. 2012), GU44AS-1 and - 3 (Halimeda fringe, 27 Aug. 2012), GU44BN-3 (Plectroglyphidodon farmer-fish territory, 8 Sep. 2015), GU76A-2 (Vecky's Reef, Apra 

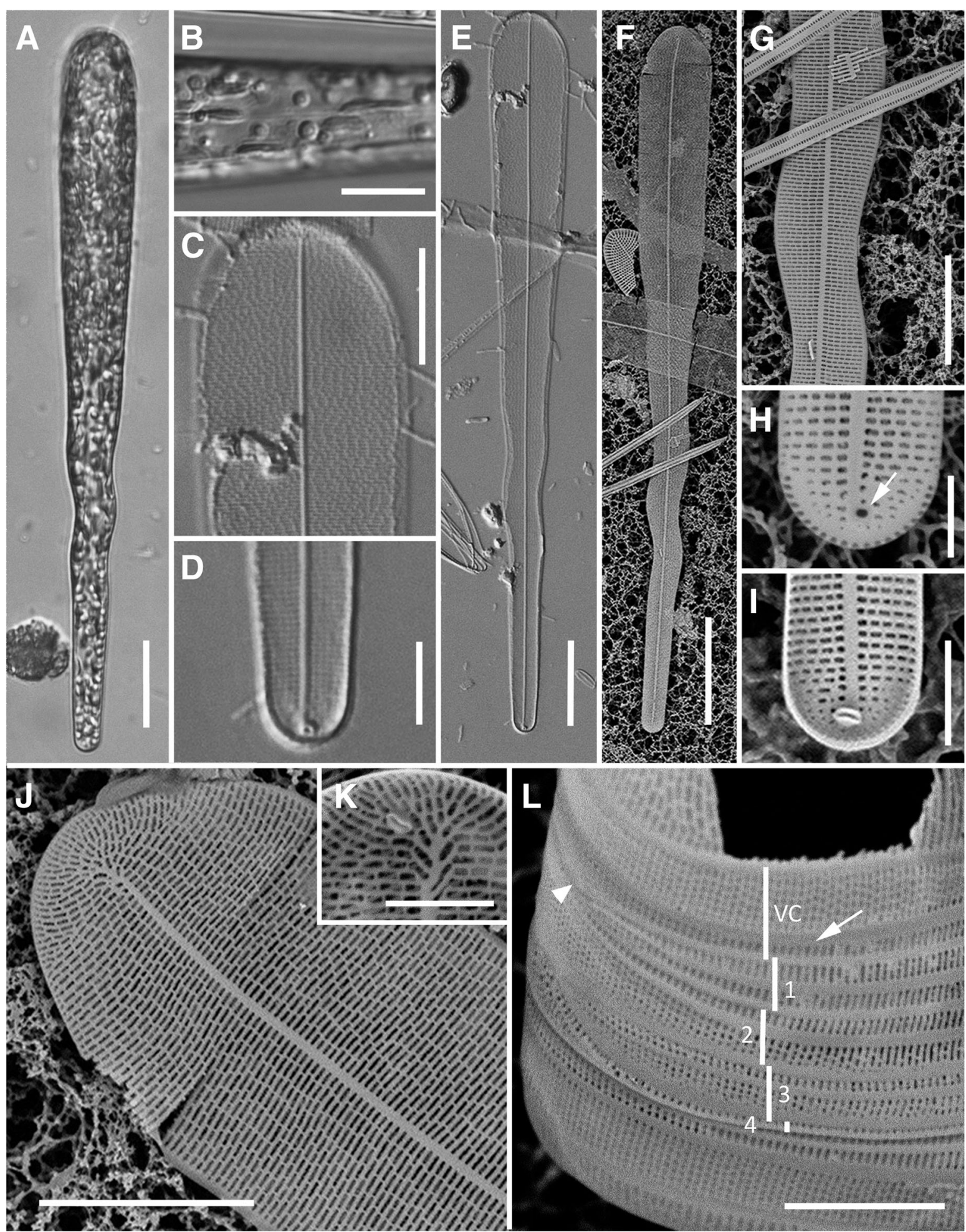

Fig. 1 L. repanda n. sp., frustules $(\mathbf{a}, \mathbf{b})$ and valves, LM (a-e) and SEM $(\mathbf{f}-\mathbf{I})$. a Live cell in valve view. $\mathbf{b}$ Detail of plastids. c-e Holotype. c-d Enlargements of apex and base showing areola pattern. e Entire valve showing foot pole rimoportula and wave. $\mathbf{f}$ Entire external view of valve in SEM. $\mathbf{g}, \mathbf{h}$ Details of ( $\mathbf{f})$ showing wave $(\mathbf{g})$ and basal pole $(\mathbf{h})$ with rimoportula opening (indicated by arrow), to the right of the midrib, and multiscissura. i Internal view of basal pole with rimoportula. $\mathbf{j}$ External view of apex showing areolae. $\mathbf{k}$ Detail of internal apex showing rimoportula. I Girdle view showing the valvocopula (VC) and four pleurae (1 through 4) and the position of the VC midrib near the abvalvar margin (arrow). Note the broadening of the abvalvar side into a broad ligule (arrowhead). Scale bars: a-e, $\mathbf{g}, 10 \mu \mathrm{m}, \mathbf{f}, 20 \mu \mathrm{m}, \mathbf{h}, \mathbf{j}, \mathbf{l}, 5 \mu \mathrm{m}, \mathbf{i}, 4 \mu \mathrm{m}, \mathbf{k}, 3 \mu \mathrm{m}$ 

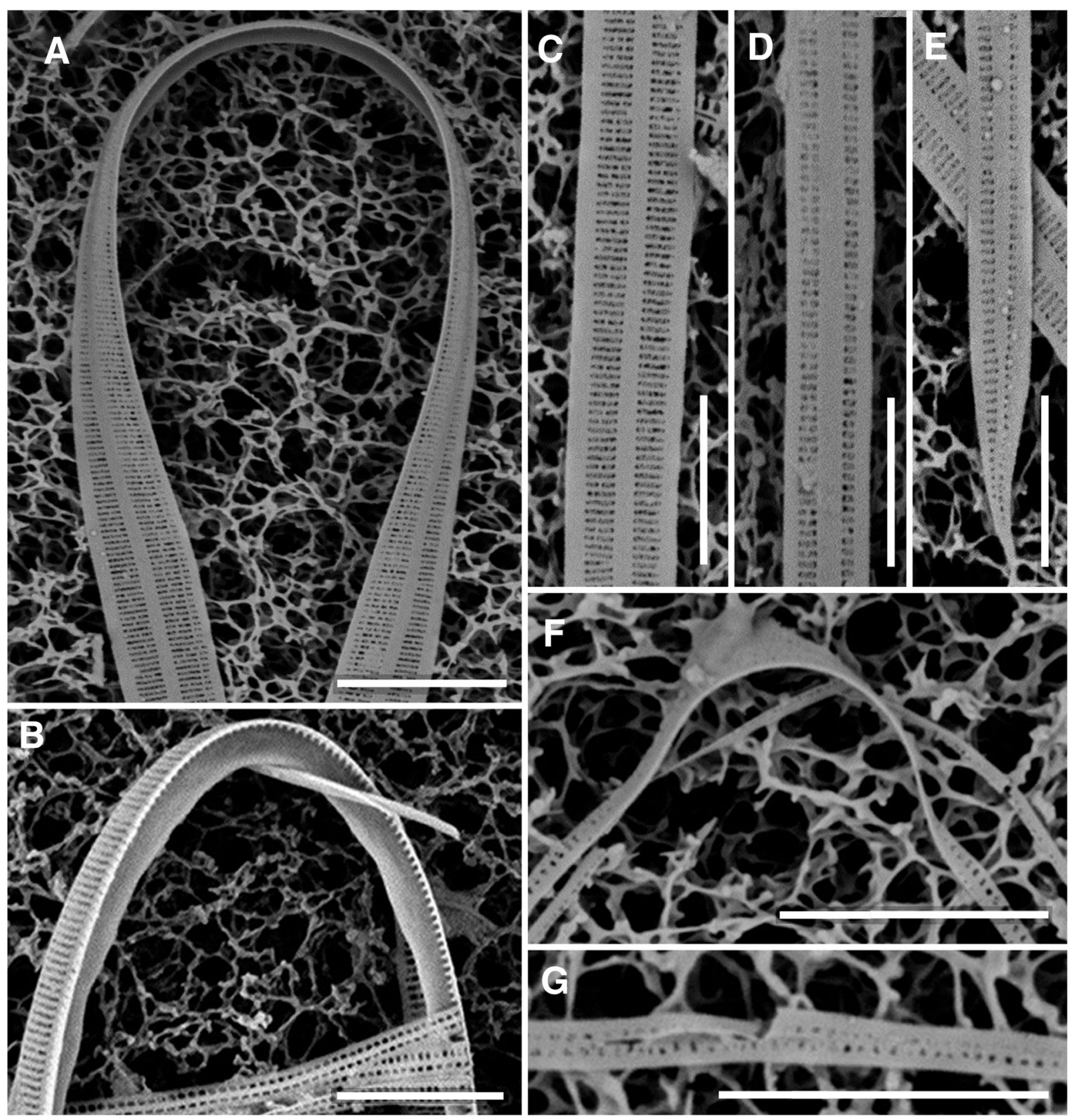

Fig. 2 L. repanda n. sp., valvocopula (a-e) and 4th pleura $(\mathbf{f}, \mathbf{g})$ in SEM. a Closed end of valvocopula with narrow septum. b Closed end of valvocopula with wider septum. c-e Series of views along same specimen as (a) showing continued midrib transition toward advalvar margin (to right) (cf. Fig. 1k), and changes in midrib width. $\mathbf{f}, \mathbf{g}$ The 4th pleura showing apical cap and portion of band with single row of pores. Scale bars $5 \mu \mathrm{m}$

Harbor; Halimeda in Plectroglyphidodon territory, 27 July 2017), GU68C-5 (Western Shoals, Apra Harbor, Halimeda in Plectroglyphidodon territory, 29 May 2017), and others.

\section{Morphology}

Samples were available from several collection times from GabGab and several different locations in and near Apra Harbor. Characteristics of valves and girdle bands from different samples were alike. Frustules were attached by long, single-stranded stalks. Plastids were elongated discs (Fig. 1b).

Valves (Fig. 1) were 190-215 $\mu \mathrm{m}$ long, $17 \mu \mathrm{m}$ wide at apex gradually tapering from apex to base, basal pole not inflated (Fig. 1a, d-f, h, i). Multiscissura with 23-26 slits (Fig. 1h, i). Striae $25-30$ in $10 \mu \mathrm{m}$, areolae $12-14$ in $10 \mu \mathrm{m}$, fairly uniform (Fig. 1c, j). Three rimoportulae, all ca. $0.8 \mu \mathrm{m}$ across inside (Fig. 1i, k), 
the two apical ones at the end of the sternum on the edge of the valve face, oriented along one of the radiating striae; external opening hard to distinguish (Fig. 1j). Basal pole width increased from $4.8 \mu \mathrm{m}$ at end of multiscissura to $5.2 \mu \mathrm{m} 10 \mu \mathrm{m}$ from base, and continued gradually increasing towards apex. One to two waves were usually present (Fig. 1a, e-g), but we observed two populations (GU44AL-2A and GU44AR-3) that were straight but proved to be otherwise indistinguishable from $L$. repanda.

Valvocopula (Fig. 2a-e) with a narrow septum (0.9$1.3 \mu \mathrm{m}$ wide) (Fig. 2a), open ends tapering abruptly and symmetrically (Fig. 2e), closed end with broad ligule on abvalvar side (shown as unnamed species in Lobban et al. 2018, Fig. 2). Copular striae 36-37 in $10 \mu \mathrm{m}$, apparently rimate on both sides of the midrib all the way to the open ends, where rimae becomes shorter. Midrib straight, asymmetrical, transition gradual: close to abvalvar margin near the apex but starting to move toward advalvar margin within $10 \mu \mathrm{m}$, completed ca. one third along the band.

4th pleura (Figs. $1 \mathrm{l}$ and $2 \mathrm{f}-\mathrm{h}$ ) comprised a shallow apical cap and a narrow band with one or two rows of pores and no midrib (see also apical view of whole mount of this species, then unnamed, in Lobban et al. 2018, Fig. 2).

The 1st-3rd pleurae did not have features that were useful in distinguishing among the species described here and in Lobban et al. (2018). However, the taxonomically useful pleura characters have not yet been established for the genus, so they may be useful in comparison with other species. We thus include brief descriptions here and have put the three associated plates in Additional files 1, 2 and 3.

1st pleura (Additional file 1A-D). Band bluntly rounded to tapered at open ends and closed end narrow with two rows of pores around the basal pole. Striae rimate; midrib symmetrical except tending toward abvalvar at open tips, wider in the middle and lower portions (ca. $800 \mathrm{vs} 400 \mathrm{~nm}$ ), then narrowing as band narrows toward basal pole (closed end).

2nd pleura (Additional file 1E-H): Band with broad ligules on both sides at the apex the advalvar ligule more clearly defined and raised into a narrow ligule with an apparently wider margin, though in apical view of whole mount there appears to be a narrow ligule on both margins. Striae rimate except around the apex, abvalvar ends of striae uneven across the ligule. Midrib symmetrical except strongly deflected toward the advalvar side around apex (Fig. 1k). Midrib narrow around apex, broadest about half-way along the band.

3rd pleura (Additional file 1I-M): Band with broad, blunt open tips. Asymmetrical, midrib toward the advalvar side. Abvalvar striae porate to nearly half the distance from the open end, then rimate; advalvar striae rimate throughout.

Licmophora undulata, n. sp. Macatugal, Tharngan \& Lobban

(Figs. 3, 4 and 5)

\section{Diagnosis}

Cells on mucilage pads. Valve length $150-200 \mu \mathrm{m}$, width $10-15 \mu \mathrm{m}$, inflated basal pole. Striae $30-35$ in $10 \mu \mathrm{m}$. Areolae significantly elongated along sternum, about twice as long as those away from sternum. Apical rimoportula only on front valve, at end of sternum on edge of mantle. Multiscissura with 20-24 slits. Valvocopula with advalvar striae ending halfway along band. The 4th pleura an apical cap with narrow band.

\section{Type material}

Holotype: valve located at $16.4 \mathrm{~mm} \mathrm{E}$ and $7.5 \mathrm{~mm} \mathrm{~S}$ of the reference point on GU44O-F slide 507, deposited at ANSP Diatom Herbarium, accession \# 20083. Sample collected by C. Lobban and M. Schefter, 3 Aug. 2008, GabGab reef,

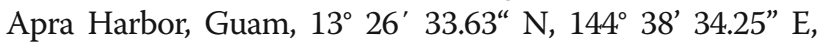
coarse red algal turf on submerged scrap metal in Stegastes nigricans farmer-fish territory in the Navy swimming pool, ca. $3 \mathrm{~m}$ deep; sample noted as being heavily dominated by the large centric diatom Stictocyclus stictodiscus. Fig. 4c-e.

\section{Etymology}

Latin, undulata = wavy.

\section{Additional materials examined}

GU44P-B (S. nigricans turf on shallow rock, 1 Sep. 2008), GU44P-E (Halimeda with fringe of diatoms, 1 Sep. 2008).

\section{Morphology}

Cells attached individually or in small groups by mucilage pads with oval plastids (Fig. 4b). Valve length ranged from 150 to $200 \mu \mathrm{m}$ and $10-15 \mu \mathrm{m}$ wide at the apex, gradually tapered from apex to base with an inflated basal pole (Figs. 3 and 4a, c, g, f, j, k). Multiscissura with 20-24 slits (Fig. 4j, k). Striae 30-35 in $10 \mu \mathrm{m}$; areolae markedly long along the sternum (Fig. 4h), ca. $7 \mathrm{x}$ longer than wide (where wide is in apical direction). Areolae 10-12 in $10 \mu \mathrm{m}$. Apical rimoportula at end of sternum on the edge of the valve face, small, apically oriented. Basal rimoportula further from pole (2 striae) than in L. repanda (Fig. $4 \mathrm{j}$ ). Basal pole width at apex of multiscissura ca. $4.2 \mu \mathrm{m}$, but $10 \mu \mathrm{m}$ from base ca. 2.5, whereas in $L$. repanda, width of pole was slightly wider and got continually wider. In $L$. undulata, there was a \pm parallel section until the first wave, then gradually wider. 


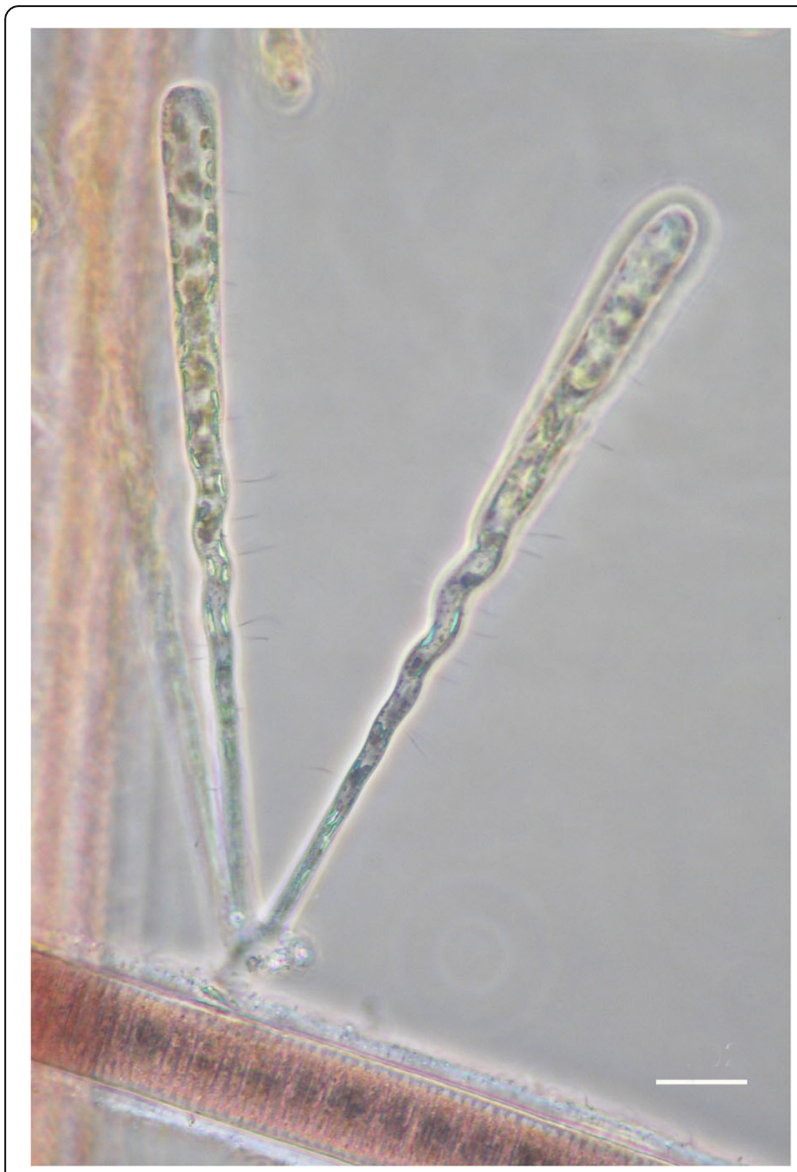

Fig. 3 L. undulata n. sp., living cells attached by mucilage stalk to a cyanophyte filament, showing axial waves mid-valve. Scale bar $20 \mu \mathrm{m}$

Valvocopula (Fig. 5a-e) with narrow septum (ca. $1.25 \mu \mathrm{m}$ ) (Fig. 5a), advalvar striae ended halfway along the band (Fig. 5c), leaving a wide margin and midrib on advalvar side, alongside the abvalvar row of slits. Midrib asymmetrical throughout, deflected toward the abvalvar side around the apex (Fig. 5b). The midrib did not get wider but became continuous with the abvalvar margin.

4th Pleura (Fig. 5f-h). Band with shallow apical cap and a band that tapered toward open end. A single row of rimate striae along the band.

1st pleura (Additional file 2A-E): Band semi-blunt rounded to tapered at open ends, closed end narrow with a single row (10-15 pores) around the basal pole (Additional file 2E). Striae rimate throughout. Symmetrical, $1.8 \mu \mathrm{m}$ wide near the open ends. Midrib widest in the middle.

2nd pleura (Additional file 2F-I): Almost symmetrical band that tapers to open end. Striae rimate throughout. Striae on one side discontinued about $7 \mu \mathrm{m}$ from the basal pole. The midrib was slightly wider around the apex. 3rd pleura (Additional file 2J-M): asymmetrical with a wide blunt open end, porate on one side of midrib near apex and rimate throughout on the other. Valves not observed in whole mount girdle view, so not known which side was advalvar.

\section{Licmophora joymaciae, n. sp. Macatugal \& Lobban}

(Figs. 6 and 7)

\section{Diagnosis}

Colonies on long single-stranded mucilage stalks. Valves length $300-400 \mu \mathrm{m}$, width $17-20 \mu \mathrm{m}$ at apical pole. Stria density different toward basal and apical poles, 26-28, 30-35 respectively. Areolae fairly uniform, transapically rectangular, long side $2 \mathrm{x}$ short side. Three rimoportulae, the apical rimoportulae on edge of valve face beyond sternum. Multiscissura with ca. 26-29 slits. Valvocopula with advalvar striae ending halfway along band. The 4th pleura a relatively large apical cap with narrow band.

\section{Type material}

Holotype: valve located at $19.8 \mathrm{~mm} \mathrm{E}$ and $9.2 \mathrm{~mm} \mathrm{~S}$ of mark on GU68B-5 slide 2046, deposited at ANSP Diatom Herbarium, accession \# 20084. Sample collected by C. Lobban and M. Schefter, 3 Apr. 2016, Western

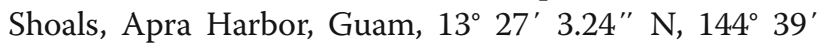
20.16" E, dense fringe of Licmophora spp. on Halimeda from S. nigricans territory, ca. $7 \mathrm{~m}$ deep.

\section{Etymology}

Named for the senior author's mother, Joy Macatugal, who encouraged the author to pursue this undergraduate research opportunity.

\section{Morphology}

Colonies on long single-stranded mucilage stalks; frustules narrowly cuneate in both valve and girdle view. Plastids numerous small oval plates.

Valves (Fig. 6) 300-400 $\mu \mathrm{m}$ long, $17-20 \mu \mathrm{m}$ wide at apex gradually tapering from apex to base (Fig. 6a, e, f), basal pole not inflated $(6 d, j, k)$. Stria density $30-35$ in $10 \mu \mathrm{m}$ at the apex and $26-28$ at the base, pattern of areolae uniform (Fig. 6c, h, i). Apical rimoportulae on edge of valve face beyond the sternum, oriented more or less in the apical plane along one of the radiating striae (Fig. 6h, i); Fig. 6j and the relative sizes of internal and external openings suggest the rimoportula is a funnel about $1.5 \mu \mathrm{m}$ across inside. Basal rimoportula at end of sternum, on the right, also about $1.5 \mu \mathrm{m}$ wide. Multiscissura with $26-$ 29 slits (Fig. 6j, k). 


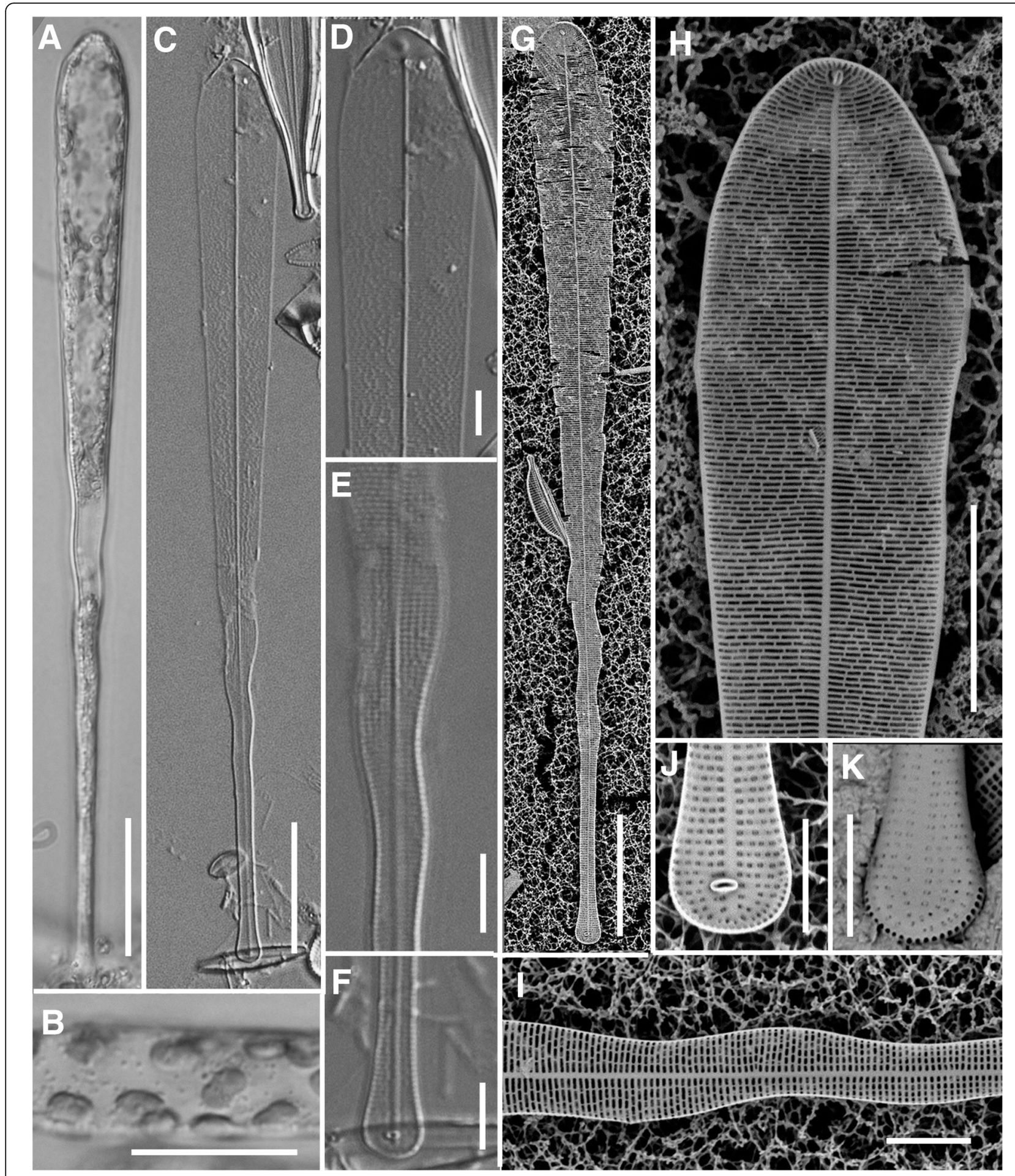

Fig. 4 L. undulata n. sp., valve (a-k). a, b Live cell in valve view. b Detail of live cell showing pyrenoids. c Entire holotype valve; details in series of views (d-f) showing elongated areola pattern along sternum, waves, and an inflated footpole with rimoportula. $\mathbf{g}$ Entire internal view of valve in SEM. $\mathbf{h}$ Internal view of the apex of a different specimen with elongated areolae along sternum and an apically oriented rimoportula. $\mathbf{i}$ Detail of wave character in same valve as $(\mathbf{g})$. $\mathbf{j}$ Internal view of basal pole with multiscissura and a rimoportula to the left of the midrib. $\mathbf{k}$ External view of basal pole with multiscissura. Scale bars: $\mathbf{b}, \mathbf{d}-\mathbf{f}, \mathbf{h}-\mathbf{i}, 10 \mu \mathrm{m}, \mathbf{a}, \mathbf{c}, \mathbf{g}, 20 \mu \mathrm{m}, \mathbf{j}-\mathbf{k}, 5 \mu \mathrm{m}$ 


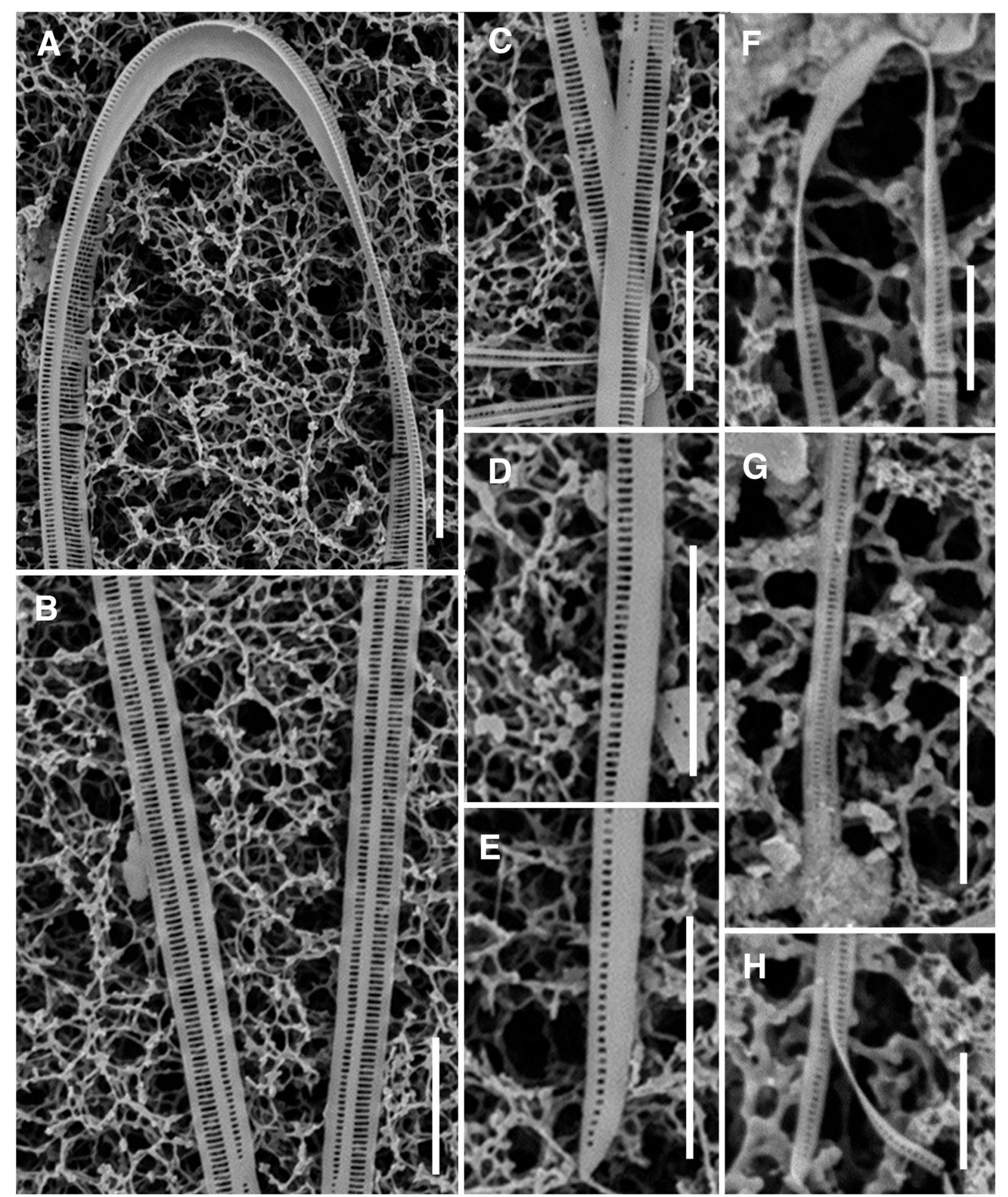

Fig. 5 L. undulata n. sp., valvocopula (a-e) and 4th pleura (f-h) in SEM. a Closed end of valvocopula with a narrow septum and midrib near abvalvar margin. $\mathbf{b}$ Mid part of band showing transition of midrib toward the advalvar margin, advalvar striae becoming shorter toward the base. c, $\mathbf{d}$ More basal portions of the band showing lack of advalvar striae. e Open end of valvocopula. $\mathbf{f}-\mathbf{h}$ A 4th pleura showing apical cap and portion of band with single row of pores throughout the whole band. Scale bars: $\mathbf{a}-\mathbf{e}, \mathbf{g}, 5 \mu \mathrm{m}, \mathbf{f}, \mathbf{h}, 2.5 \mu \mathrm{m}$ 


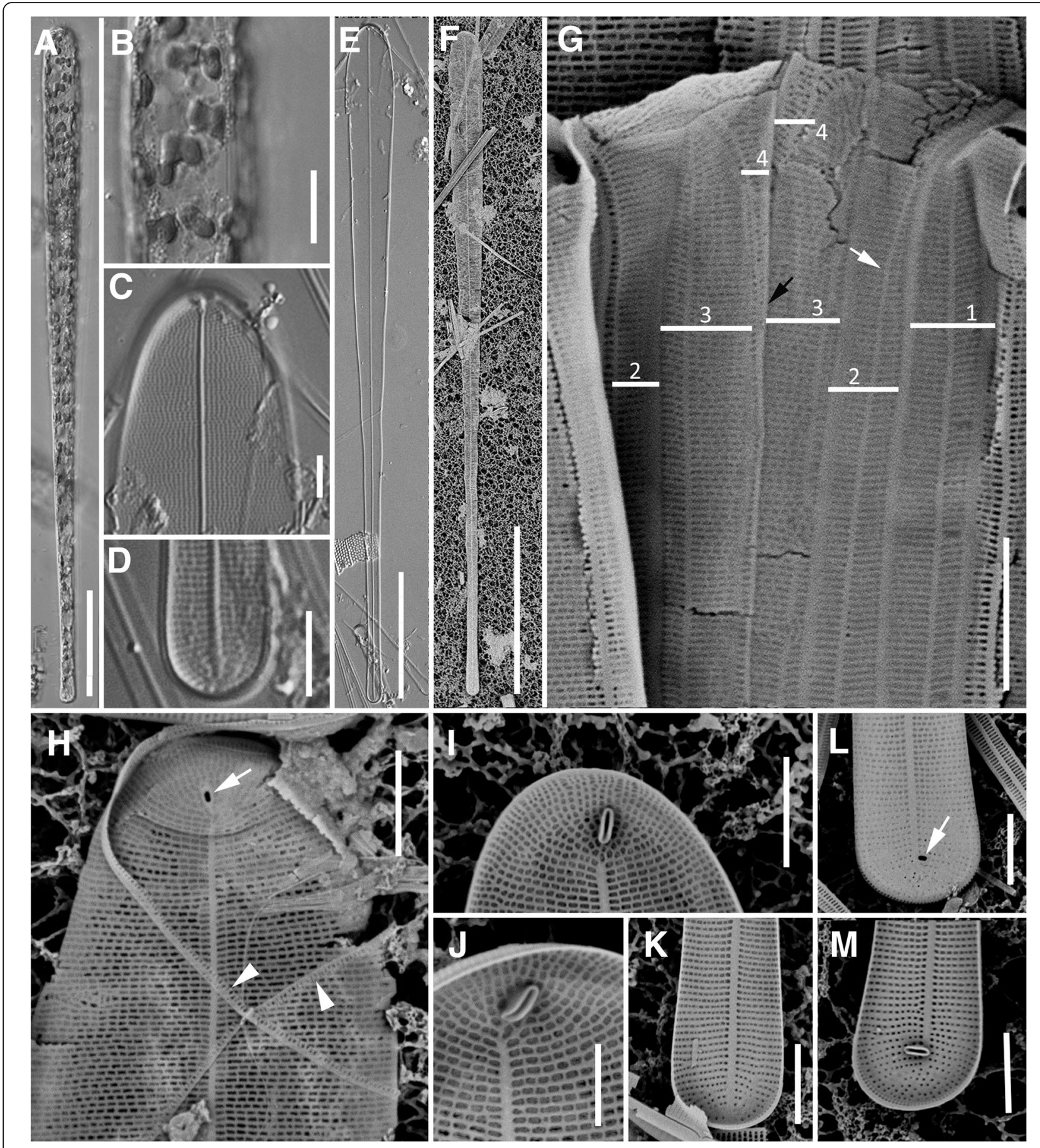

Fig. 6 L. joymaciae n. sp., valve (a-f) and frustule (g); (a-e DIC, f, g SEM). a, b Live cells in valve view, showing plastids. c-e Holotype. c Apex with rimoportula, $\mathbf{d}$ basal pole, e entire valve. $\mathbf{f}$ Entire external view of valve in SEM. $\mathbf{g}$ Girdle view showing the four pleurae (1 through 4). White arrow shows midrib of 2nd pleura swung towards advalvar side and black arrow shows where abvalvar striae are lost on 4th pleura. $\mathbf{h}$ External view of apex with rimoportula opening (arrow), also showing portion of the 4th pleura (arrowheads). $\mathbf{i}$ Internal view of apex with rimoportula and uniform pattern of striae along septum. $\mathbf{j}$ Oblique internal apex showing shape of rimoportula. $\mathbf{k}$, I External view of basal pole with rimoportula opening (arrow). $\mathbf{m}$ Internal view of basal pole with rimoportula. Scale bars: $\mathbf{a}, \mathbf{e}, 50 \mu \mathrm{m}$. b-d, $10 \mu \mathrm{m}$, $\mathbf{f}, 100 \mu \mathrm{m}, \mathbf{g}-\mathbf{i}, \mathbf{k}-\mathbf{m}, 5 \mu \mathrm{m}, \mathbf{j}, 2.5 \mu \mathrm{m}$ 


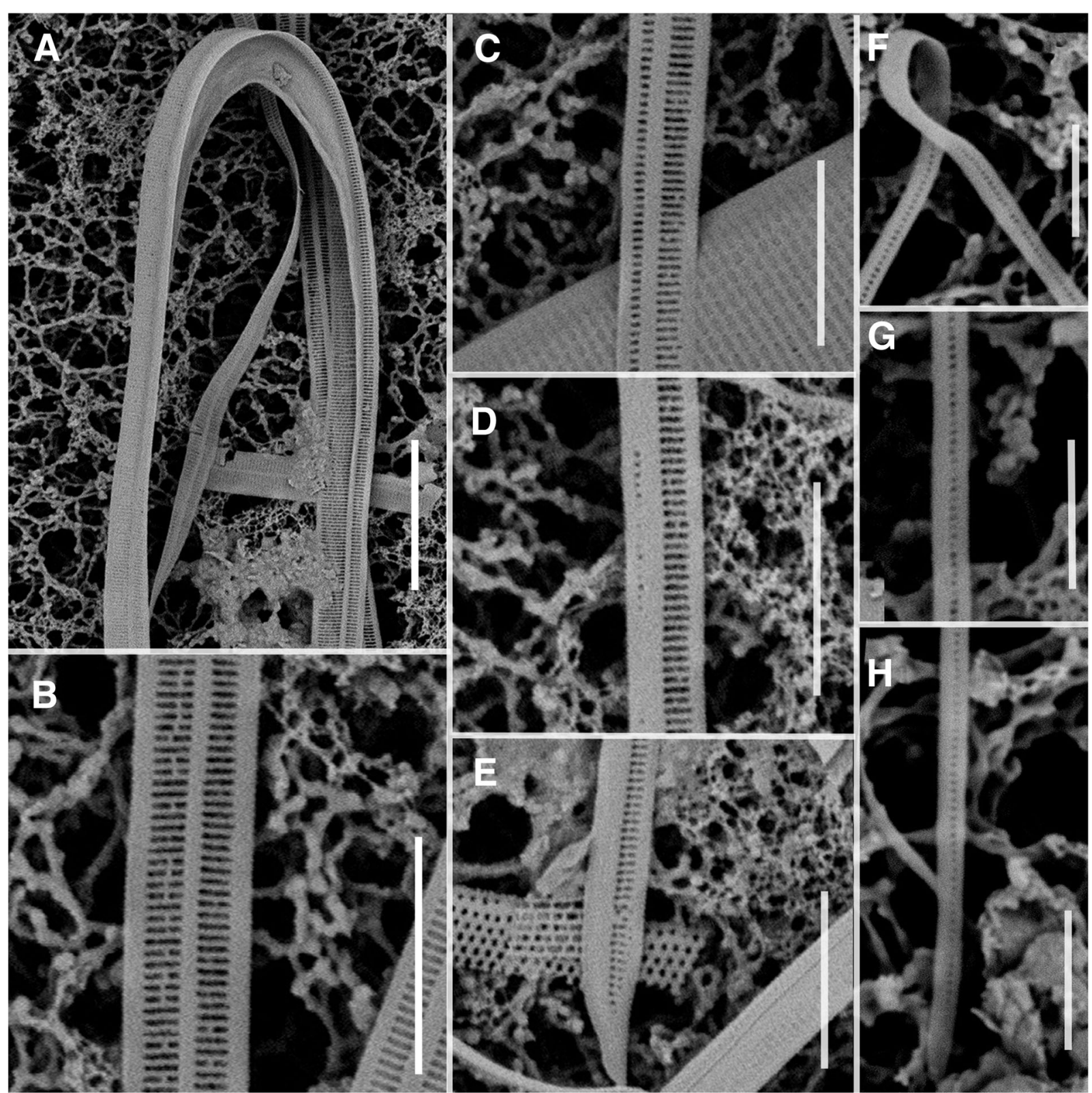

Fig. 7 L. joymaciae n. sp., valvocopula (a-e) and 4th pleura (f-h) in SEM. a Closed end of valvocopula with narrow septum, midrib/septum on abvalvar side. b Band appears symmetrical as midrib swings gradually. c-e Advalvar striae peter out as midrib moves completely to advalvar side. $\mathbf{f}-\mathbf{h}$ The 4th pleura showing apical cap and portion of band with single row of pores that runs throughout the whole band. Scale bars: $\mathbf{a}$, $10 \mu \mathrm{m}$, b-e, $5 \mu \mathrm{m}, \mathbf{f}-\mathbf{h} 2.5 \mu \mathrm{m}$

Valvocopula (Fig. 7a-e) with a narrow, solid septum ( $2.75 \mu \mathrm{m}$ wide) (Fig. 7a). Copular striae $41-42$ in $10 \mu \mathrm{m}$. Midrib gradually moved from abvalavar to advalvar margin (Fig. 7a), eliminating the advalvar striae about halfway along the band (Fig. 7 d, e).

4th Pleura (Figs. 6g and 7f-h): Band comprised a relatively large apical cap and a narrow band with initially two rows of rimae, the abaxial one soon ending (Fig. 6g).

1st Pleura (Fig. 6g, Additional file 3A-E): Band sharply rounded to tapered at open ends, closed end narrow with two rows of pores around the basal pole. Midrib symmetrical throughout band, widening towards the closed end.

2nd Pleura (6g, Additional file 3F-K): Symmetrical band. Striae of rimae that end on both sides about $10 \mu \mathrm{m}$ from open end.

3rd Pleura (6g, Additional file 3L-P): Band with blunt open tips that taper toward basal pole. More or less symmetrical, midrib toward the advalvar side. Striae on both sides porate to about $40 \mu \mathrm{m}$ from open ends, then 


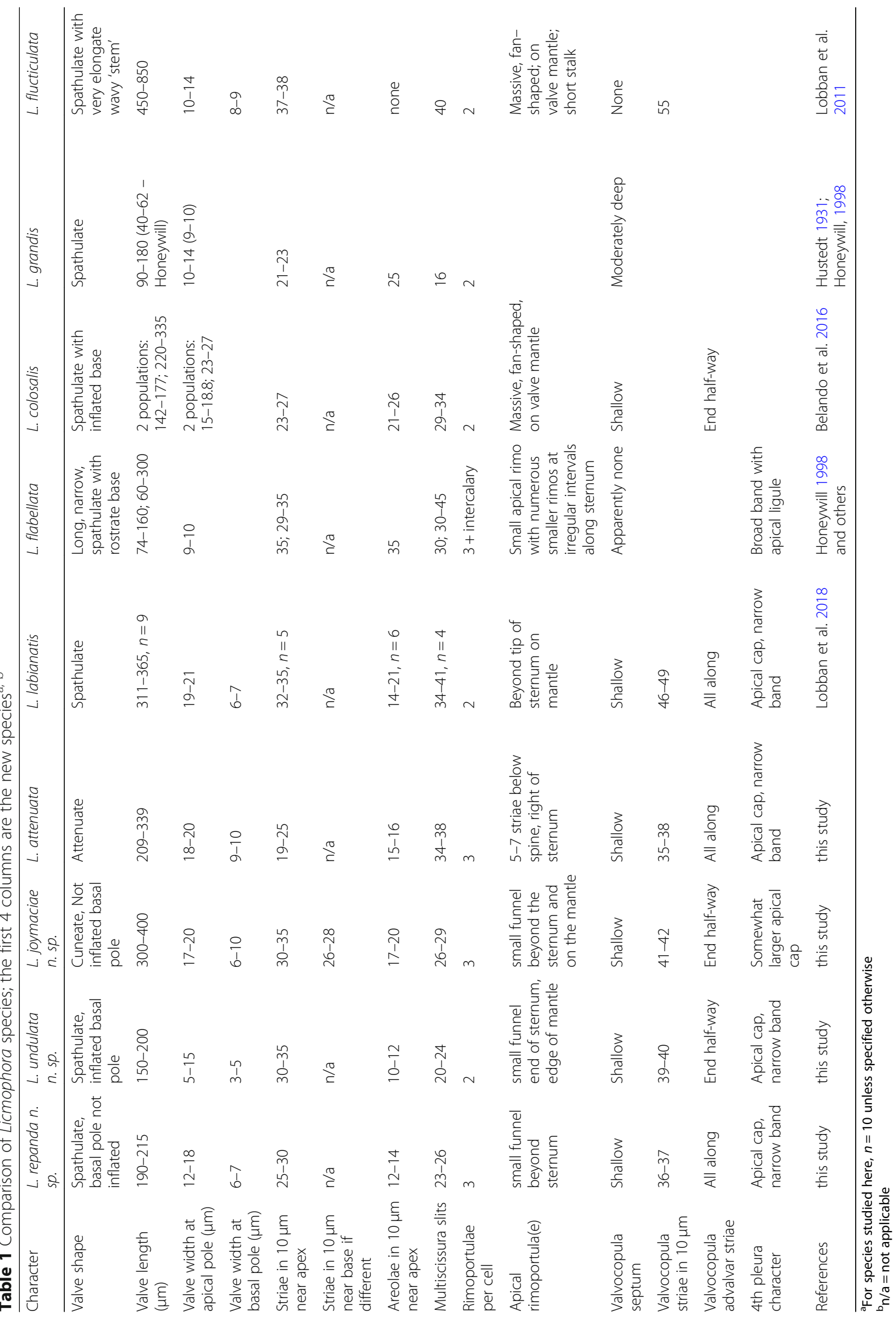


rimate throughout rest of band. Midrib wider in the middle part of the band.

\section{Discussion}

Of the three species treated here, two are distinct from other Licmophora species by the presence of 1-2 waves in the mid-lower part of the valve. In one of these species we observed specimens without a wave. The third species was always straight. The three species were readily distinguished from each other by the combinations of characters (Table 1).

$L$. undulata and $L$. repanda were initially confounded because of the distinctive lateral wave in the valve and similar lengths of the cells, but can be clearly distinguished by valve shape, areolae, rimoportulae, and valvocopulae. Whereas $L$. repanda was broad, with a nearly uniform taper to a fairly wide basal pole, L. undulata was narrower and tapered to a slender stalk that ended in an inflated basal pole. In both species the sternum was straight despite the wave(s) in the valve margins. Stria density was slightly coarser in $L$. repanda ( 27 vs. 33 in $10 \mu \mathrm{m}$ ). The areolae along the sternum were conspicuously longer than others in the striae in L. undulata, whereas in L. repanda areolae were irregularly elongate as in $L$. undulata, but not significantly longer along the sternum. Both species had more elongate areolae than $L$. joymaciae. The two wavy species also differed significantly in the character of the valvocopula, although the septa were similar. L. undulata (as in L. joymaciae and L. labianatis) lost advalvar striae halfway along but in $L$. repanda there were rimae on both sides to the open tip. There were only small differences in the first 3 pleurae. The 4th pleura was an apical cap + narrow band in L. repanda and we were unable to observe it in L. undulata.

Rimoportulae were similar in size and shape in all species, though with slight differences in position of the apical rimoportulae, but $L$. repanda and $L$. joymaciae had 3 rimoportulae whereas $L$. undulata had only two. The number of slits in the multiscissura increased from $L$. undulata to $L$. repanda to $L$. joymaciae, probably in proportion to the width of the basal pole.

The presence of straight valves of $L$. repanda in two of the collections is not surprising, since we (Lobban et al. 2018) also observed straight specimens of L. curvata Lobban, Tharngan \& Ashworth that were otherwise identical to the normal, curved specimens. However, as with L. curvata, it is necessary to show that the straight specimens do not match any known Licmophora and we must also consider whether $L$. undulata might be a wavy form of something already known. L. grandis (Kützing) Grunow (Hustedt 1931; Honeywill 1998) has coarser striae and a deep septum. Licmophora paradoxa var. tincta (C.Agardh) Hustedt (Peragallo and Peragallo 1897-1908; Hustedt 1931) is shorter (up to $140 \mu \mathrm{m}$ ); stria densities ranges overlap $L$. undulata and $L$. repanda; and the septum is deep. $L$. undulata is close to the shape of some L. remulus (Hustedt 1931; Navarro and Lobban 2009; Álvarez-Blanco and Blanco 2014; Belando et al. 2016), though this species is normally strongly spathulate; stria densities are similar and the basal pole is inflated, but $L$. remulus has no septum and the stem is extremely narrow with a single areola on each side of the sternum, and its basal pole has only 11-12 slits in multiscissura. We are confident that neither $L$. undulata nor $L$. repanda is a wavy form of any known species.

$L$. joymaciae was more than double the length of the other two species and qualifies as a "giant" species; it was never wavy. As such it could not be confused with the other two species described here, but was similar to L. labianatis (Lobban et al. 2018) and L. colosalis (Belando et al. 2016). L. colosalis are somewhat shorter than L. joymaciae (two populations: $142-177$ and 220 335 , vs. $300-400 \mu \mathrm{m}$ ), but the most obvious distinction between these two species is that $L$. colosalis has "massive fan-shaped apical rimoportulae," unlike those found in L. joymaciae. L. labianatis could be easily confused with $L$. undulata because of an inflated basal pole. However, L. labianatis does not have any wave character and is distinguishable by a "shredded" zone lacking vimines, which was not observed in any of our newly described species.

In the present species, the 1st to 3 rd pleurae were not taxonomically useful. However, pleurae have been characterized in only a few Licmophora species to date. It remains to be seen whether their characters have taxonomic value in the genus as more, especially smaller species are described. The figures supplied here as Additional files 1, 2 and 3 are intended as a contribution toward an atlas of Licmophora copulae for future reference.

In the genus Licmophora on Guam, there are now 13 new species vs. 3 species that were already described (flabellata, remulus, and probably abbreviata). Three of those were originally placed in Licmosphenia but soon transferred to Licmophora when those genera were merged (Lobban et al. 2015). It is still too early to tell whether these 13 species will be found widely in the tropics or whether there will be distinct floras in different regions of the tropics. There are still many smaller taxa to determine, including " $L$. cf. ehrenbergii" in Lobban (2013) and "L. sp. 2" in Lobban et al. (2018). Some of the small species may prove identical to European taxa, but we expect that many will not.

Based on results of their study of the effect of environmental conditions on growth and stalk formation in Licmophora flabellata, Ravizza and Hallegraeff 
(2015) called for species-specific approaches toward mitigating the impact of fouling diatoms: species-conditions combinations that produce the most mucilage have the greatest impact on human society. But it is clear that one cannot get far with such work in tropical environments until there is much better knowledge of the diversity of the genus around the tropics.

\section{Additional files}

Additional file 1: L. repanda $\mathrm{n}$. sp., 1st to 3 rd pleurae in SEM. (A-D) Series of views of a 1st pleura $(\mathbf{E}-\mathbf{H})$ Series of views of a 2 nd pleura. (I-M) Series of views of a 3rd pleura. Scale bars: A, B, E, L, M $5 \mu \mathrm{m}, C, D, 2 \mu \mathrm{m}$, $\mathrm{F}-\mathrm{H}, 2.5 \mu \mathrm{m}$. (JPG $1911 \mathrm{~kb})$

Additional file 2: L. undulata n. sp., 1st to 3rd pleurae in SEM. (A-E) Series of views of the 1st pleura. (F-I) Series of views of a 2 nd pleura. (J-M) Series of views of a 3rd pleura. Scale bars: A-E, $2 \mu m, F, 5 \mu m, G-M$, $2.5 \mu \mathrm{m}$. (JPG $1736 \mathrm{~kb}$ )

Additional file 3: L. joymaciae n. sp. 1st to 3rd pleurae in SEM. (A-E) Series views of a 1st pleura. (F-K) Series views of a 2 nd pleura. (L-P) Series of views of a 3rd pleura. Scale bars: A-H, K-N, $5 \mu \mathrm{m}, \mathrm{I}, \mathrm{J}, \mathrm{O}, \mathrm{P}$, $2.5 \mu \mathrm{m}$. (JPG $2160 \mathrm{~kb})$

\section{Acknowledgements}

CSL thanks María Schefter for continuous support and encouragement with the diatom research and Captain H.E. Sholley, Commanding Officer of Nava Base Guam for continued access to collecting sites on the base. Collections of coral substrata from farmer-fish territories was done under permits from Guam Department of Agriculture, Division of Aquatic and Wildlife Resouces.

\section{Funding}

Ella Macatugal and Bernadette Tharngan were supported by internships from the Islands of Opportunity Louis Stokes Alliance for Minority Participation (LSAMP) program, funded by the National Science Foundation. The microscopes in the U. Guam Microscopy Teaching and Research Laboratory were purchased with grants from the National Institute of General Medical Sciences, Minority Opportunities in Research (MORE) Division, Research Initiatives in Scientific Excellence (RISE) program (2003-2010).

\section{Availability of data and materials}

Additional images analyzed during the current study are available from the corresponding author upon reasonable request. Raw materials, slides and stubs are retained in the University of Guam Herbarium (GUAM) Diatom collection and may be obtained on loan upon reasonable request.

\section{Authors' contributions}

EMSM did the bulk of the imaging, analysis and write-up, mentored by CSL, and based on preliminary imaging and analysis by BGT, again mentored by CSL. All authors read and approved the final manuscript.

\section{Ethics approval and consent to participate}

Not applicable.

\section{Consent for publication}

Not applicable.

\section{Competing interests}

The authors declare that they have no competing interests.

\section{Publisher's Note}

Springer Nature remains neutral with regard to jurisdictional claims in published maps and institutional affiliations.

\section{Author details}

'LSAMP Program, College of Natural \& Applied Sciences, University of Guam, Mangilao, GU 96923, USA. ${ }^{2}$ Division of Natural Sciences, University of Guam, Mangilao, GU 96923, USA.

Received: 23 August 2018 Accepted: 30 January 2019

Published online: 05 March 2019

\section{References}

Álvarez-Blanco I, Blanco S. Benthic diatoms from Mediterranean coasts. Bibl Diatom. 2014:60:1-409.

Belando MD, Aboal M, Jiménez JF, Marín A. Licmophora colosalis sp. nov. (Licmophoraceae, Bacillariophyta), a large epiphytic diatom from coastal waters. Phycologia. 2016;55:393-402.

Daniel FF, Chamberlain AHL, Jones EBG. Cytochemical and electron microscopical observations on the adhesive materials of marine fouling diatoms. Br Phycol J. 1987:22:101-18.

Giffen MH. A checklist of marine littoral diatoms from Mahé, Seychelles Islands. Bacillaria. 1980;3:129-59.

Hagelstein R. Botany of Porto Rico and the Virgin Islands. Diatomaceae. New York Academy of Sciences, Scientific Survey of Porto Rico and the Virgin Islands. 1939;8(3):313-450.

Hein MK, Winsborough BM, Sullivan MJ. Bacillariophyta (diatoms) of the Bahamas. Icon Diatom. 2008;19:1-303.

Honeywill C. A study of British Licmophora species and a discussion of its morphological features. Diatom Res. 1998;13:221-71.

Hustedt F. Die Kieselalgen Deutschlands, Österreichs und der Schweiz unter Berücksichtigung der übrigen Länder Europas sowie der angrenzenden Meeresgebiete. In: Kryptogamen-Flora von Deutschland, Österreich und der Schweiz. Band 7, Teil 2. New York: Johnson Reprint; 1931.

Lobban CS. The marine araphid diatom genus Licmosphenia in comparison to Licmophora, with the description of three new species. Diatom Res. 2013;28: 185-202.

Lobban CS. Grammatophora ornata (Fragilariophyceae: Grammatophoraceae), a new species with areolate valvocopulae, from a coral reef. Diatom. 2015a:31:12-17.

Lobban CS. A second species of Microtabella (Grammatophoraceae, Bacillariophyta) from Guam. Marine Biodiversity Records. 2015b;8:e151, 5 pp. https://doi.org/10.1017/S1755267215001293.

Lobban CS, Ashworth MP, Car A, Herwig W, Ulanova A. Licmosphenia revisited: transfer to Licmophora, redescription of L. clevei Mer., and descriptions of three new species. Diatom Res. 2015;30:227-36.

Lobban CS, Jordan RW. Diatoms on coral reefs and in tropical marine lakes. In: Smol JP, Stoermer EF, editors. The diatoms: applications for the environmental and earth sciences. 2nd ed. Cambridge: Cambridge University Press; 2010. p. 346-56.

Lobban CS, Schefter M, Ruck EC. Licmophora flucticulata sp. nov. (Licmophoraceae, Bacillariophyceae), an unusual flabellate species from Guam and Palau. Phycologia. 2011;50:11-22.

Lobban CS, Tharngan BG, Ashworth MP. Four new Licmophora species (Licmophorales), with a review of valve characters and exploration of cingulum characters, including a new septum type. Diatom Res. 2018. https://doi.org/10.1080/0269249X.2018.1473292.

Mereschkowsky C. Diagnoses of new Licmophorae. Nuova Notarisia 1901-1902;12: $141-153+13: 29-46$

Navarro JN. A survey of the marine diatoms of Puerto Rico. IV. Suborder Araphidinae: Families Diatomaceae and Protoraphidaceae. Bot Mar. 1982;25:247-63.

Navarro JN, Lobban CS. Freshwater and marine diatoms from the western Pacific islands of Yap and Guam, with notes on some diatoms in damselfish territories. Diatom Res, 2009:24:123-57.

Peragallo H, Peragallo M. Diatomées Marines de France et des Districts Maritimes Voisins. Grez-sur-Loing: M.J. Tempère: 1897-1908. p. 491 + 137 pl.

Ravizza M, Hallegraeff G. Environmental conditions influencing growth rate and stalk formation in the estuarine diatom Licmophora flabellata (Carmichael ex Greville) C.Agardh. Diatom Res. 2015;30:197-208.

Woods DC, Fletcher RL. Studies on the strength of adhesion of some common marine fouling diatoms. Biofouling. 1991;3:287-303. https://doi.org/10.1080/ 08927019109378183.

Zargiel KA, Swain GW. Static vs dynamic settlement and adhesion of diatoms to ship hull coatings. Biofouling. 2014;30:115-29. https://doi.org/10.1080/ 08927014.2013.847927. 